\title{
Erratum to: Genome-wide Identification and Comparative Structural Analysis of RuBisCo Proteins in the Asteraceae
}

\author{
Murat Kemal Avci ${ }^{*}$ and Erdem Tezcan ${ }^{2}$ \\ ${ }^{1}$ Department of Agricultural Biotechnology, Adnan Menderes University, Aydin 09970, Turkey \\ ${ }^{2}$ Department of Molecular Biology-Genetics and Biotechnology, Istanbul Technical University, Istanbul 34469, Turkey \\ *Corresponding author: muratkemalavci@yahoo.com, murat.kemal@adu.edu.tr
}

(C) Korean Society for Horticultural Science and Springer 2016

Erratum to: Hortic. Environ. Biotechnol. 57(4):404-414. 2016.

DOI 10.1007/s13580-016-0010-3

The original online version of this article contained an error in the author's list.

The correct author's list should be given as Murat Kemal Avci ${ }^{1 *}$ and Erdem Tezcan2 not Murat Kemal Avci ${ }^{1 *}$, Erdem Tezcan ${ }^{2}$, and Emre Sevindik ${ }^{1}$ 